\title{
Fair Trade as a Social Enterprise: Oversold, Misunderstood or Unethical? ${ }^{1}$
}

\author{
Sushil Mohan; Arvind Upadhyay; Nikolaos Daskalakis; Ridhima Durham²
}

${ }^{1}$ Brighton Business School, University of Brighton, Brighton BN2 4AT, United Kingdom

${ }^{2}$ Independent Researcher, 236 Randolph Avenue, London W9 1PF, United Kingdom

\section{Correspondence}

Sushil Mohan, Brighton Business School, University of Brighton, Brighton BN2 4AT, United Kingdom.

Email: s.mohan@brighton.ac.uk

\section{Main Message}

Although the concept of Fair Trade blends with the concept of 'social enterprises', but a critical examination of the theory and practice of Fair Trade shows that considering Fair Trade as an obvious example of 'social enterprise' would mean a dilution of the social context of 'social enterprises'.

\section{Key points}

Fair Trade organisations and businesses are widely referred to as 'social enterprises' because the concept of Fair Trade blends with the concept of 'social enterprises'. As the Fair Trade market has grown, so have the debates about its benefits and business ethics. A critical examination of these debates shows that Fair Trade is just a speciality marketing device that offers benefits similar to other speciality marketing mechanisms in the market. Fair Trade should therefore be treated no differently from other similar social marketing and labelling initiatives in the market and considering Fair Trade as an obvious example of 'social enterprise' would mean a dilution of the social context of 'social enterprises'.

\footnotetext{
${ }^{1}$ JEL Classification Codes: D11, F13, L31, M31, O13, Q13
} 


\section{INTRODUCTION}

Social enterprises are commonly defined as enterprises that trade for a social or environmental purpose. Meeting their social and/or environmental aspirations does not qualify an enterprise 'social', for that they have also to adopt commercial market-oriented approaches to meet financial and commercial aspirations (Grant and Palakshappa, 2018). Fair Trade (hereafter FT) organisations and activities are widely accepted as examples of social enterprises as they combine economic activity and social mission in an innovative manner (Huybrechts, 2010). ${ }^{2}$ For example, FT aims to produce social benefits for a target group (producers and workers of primary commodities in developing countries) utilising market-based approaches of trade and commerce (Mason and Doherty, 2016). FT manifests as a social enterprise in terms of managing the tensions between commercial opportunity exploitation and the pursuit of the social mission (Smith et al., 2013). In addition, FT is engaged in campaigning for changes in rules and practice of conventional trade to achieve greater equity in international trade. Organisations directly trading in FT are referred to regularly as 'FT social enterprises' as FT is considered as having contributed to the shaping of 'social enterprises' theoretical concepts (Huybrechts and Jacques 2008; Nicholls, 2010). The objective of this paper is to evaluate to what extent trading in FT makes an enterprise 'social'.

\footnotetext{
${ }^{2}$ We use the term 'Fair Trade' in a wider context to refer to a product certified by a body which demands certain conditions of and/or makes particular guarantees to the producers of the relevant products as well as to the movement and organisations that promote and trade in 'Fair Trade' products.
} 
The growth of the FT market is both unique and controversial since FT products generally sell for more than comparable conventional products without delivering extra (physical) quality. FT relies on campaigning for growth in its market, which tends to blame 'unjust' market relationships for the plight of producers and workers in developing countries. Moreover, the campaigning tends to convey the impression that FT's success is contingent upon increasing consumer awareness of the exploitative nature of conventional global trade and multinational corporations. FT enthusiasts participate in protests highlighting the exploitative nature of multinational corporations' control and unfair advantage, though lately this is being diluted because of the increasing participation of large corporations in the FT movement. The proponents of FT claim that FT addresses the vulnerability of producers: as a part of Trade Justice campaign, FT seeks greater equity in international trade by challenging market competitiveness based solely on price, challenging "the injustices of conventional trade” and trying to create more egalitarian trade between Northern consumers and Southern producers. Fair Trade seeks to contribute "to sustainable development by offering better trading conditions to, and securing the rights of, marginalized producers and workers - especially in the South.” The FT minimum price acts as a vital safety net for farmers and workers and protects them from fluctuations in the market prices of the products they grow for a living. This protection ensures they can have an assured and stable income and plan for their future. Fairtrade is the only certification scheme that offers such a unique minimum price protection for farmers (Fairtrade Foundation, 2016).

The FT claims and protestations draw reactions from commentators who believe in the many virtues of conventional international trade and free market mechanisms including the critical role they can play in improving the conditions of poor producers and workers in developing countries. 
Moreover, as the visibility of FT has grown over the years and as more and more organisations embrace FT to assert their 'social enterprise' activities and commitment, the claims made by FT have attracted increased scrutiny. Moreover, a number of commentators have misgivings about the vision, business ethics and practices of FT (Griffiths, 2012). This paper identifies the following claims made by proponents of FT for further scrutiny.

- Does FT challenge unequal trading relationship?

- Does FT mislead consumers in believing that most of the extra premium they pay for FT products reaches producers?

- Does FT secure producers against the volatility of market prices?

The paper then examines how the benefits of FT compare with those of other similar trading relationships operating in the market?

The objective of this paper is to analyse the theory and practice of FT in order to provide critical insights on the above-mentioned questions and to answer the question whether trading in FT makes an enterprise 'social'. It emerges from the analysis that FT is just a niche/alternative speciality marketing device within the free market system that offers benefits that are more or less similar to other niche speciality mechanisms operating in the market. It is both wrong and unethical on the part of proponents of FT to campaign that it is a mechanism for challenging unequal trading relationship and correcting the so-called injustices of global trade and securing producers from the vagaries of the market. Such a campaigning undermines the role of conventional international trade and other market-based mechanisms that offer immense possibilities for the upliftment of poor producers and workers in developing countries. The conclusions show that considering FT enterprises 'social' poses a risk of dilution of the social context of 'social enterprises'. Therefore 
enterprises have to go beyond selling of FT products to be classified as 'social'. The insights also have an important bearing in shaping the future of FT as well as understanding the costs and benefits of social labelling initiatives.

The rest of the paper is organised as follows. Section 2 outlines the features of the FT system and presents its sales profile. Section 3 to 5 scrutinises the above-listed claims made by proponents of FT. Section 6 analyses how the benefits of FT compare with other similar trading relationships operating in the market. Section 7 concludes.

\section{FAIR TRADE SYSTEM AND PROFILE}

FT is an organised social movement aimed at offering better conditions to improve the lives of marginalised producers and workers in areas related to production and trading of (mainly) agricultural commodities. It does so without being involved directly in commodity production or trade, rather by certifying the observance of standards through labelling and by campaigning to promote the market for FT products. The movement focuses mostly on exports of agricultural commodities from developing countries to developed countries. The understanding of FT is best conveyed by the criteria required for FT certification:

- Traders pay producers an agreed minimum price that covers the costs of sustainable production and living, which gives way to the market price whenever this is above the minimum. Traders should also provide a social premium, around 5 to 10 per cent of the fixed minimum price, for development and technical assistance. 
- FT producers must follow standards regarding working conditions, wages, child labour and the environment. These include adherence to the ILO standards, the UN charter of human rights, and protection and conservation of the environment (genetically modified crops are banned).

- Traders, as far as possible, must directly purchase from producers or producer organisations using long-term contracts to lessen the number of intermediaries and to promote long-term planning and stability.

- Traders should help provide producers credit, up to 60 per cent of purchase amount in advance, when requested.

- The producers or producer organisations must be certified by the specially set up FT certification company FLO-CERT. The supply chain must also have been monitored by the FLO-CERT. FT certification procedures vary between products and organisations. For key commodities like coffee and cocoa certification is available only to producer organisations (cooperatives of producers). However, for other commodities such as bananas, tea and fruit certification is available to large agricultural businesses.

In 2016 FT products were produced by over 1.6 million farmers and workers across 73 countries and 1441 producer organisations were active in supplying FT products (FLO, 2018). Global sales of FT products in 2016 amounted to $€ 7.88$ billion; it is worth noting that growth of FT has not been uniform across all countries, rather it has been restricted to few countries, with UK being the largest market followed by Germany; in 2016 market sales of FT amounted to $€ 1.6$ billion in the UK and $€ 1.15$ billion in Germany (FLO, 2018). While coffee still constitutes a large component of FT sales, the number of products sold with FT labels has been increasing. Retail sales of major items in volume over the last few years are given in Table 1. 
At best FT sales represent a fraction of global food and beverage industry sales with estimates at around 0.01 per cent (Nicholls and Opal, 2005; 230). Even FT coffee, which is the highest selling FT product, its sales represent around 1.55 per cent of world coffee exports (ICO, 2016; FLO, 2016). However what is distinctive is that the growth rate of FT sales has been strong: annual sales grew at a rate of 40 per cent over 1998-2007 and about 12-13 percent over 2007-2016.

\section{[Insert Table 1 here]}

The discussion above tells us that the FT is important because of continued strong growth in market and that the FT concept embodies an economic (trade), a social (producer support) and an advocacy (challenging conventional trade as socially focused competitors) dimension. Since the FT concept brings together the commercial and fairness elements, FT trading is treated as an obvious example of 'social enterprises'. In the sections following we analyse the theory and practice of FT to draw whether trading in FT makes the activities or enterprises 'social'.

\section{DOES FT CHALLENGE UNEQUAL TRADING RELATIONSHIP?}

The proponents of FT often depict it as an alternative to the hegemony of free trade and an attempt to create alternative distribution channels to combat the structure of world trade that is regarded as unjust. It is often suggested that FT is different from free-market trade 'by offering better trading conditions to, and securing the rights of, marginalised producers and workers'. The impression portrayed is as if economic thinking has to be left behind when entering the sphere of FT. However, 
FT is very much a market-responsive model of trade, a consequence of consumer society requiring participants to make a profit. With respect to their substance FT and traditionally marketed products show at most very little divergence and hardly differ with respect to their functional utility. They merely differ in terms of following certain production and trading standards that affect the circumstances under which the goods are produced and marketed. This makes FT very similar to a speciality market operation like that for organic products or local produce.

Most economic analyses assume that rational consumers maximise their subjective expected utility, under given constraints, by choosing from a set of available options the alternative that maximises utility. On a priori grounds, the behaviour of an FT consumer deciding in favour of the relatively more expensive FT product over a relatively similar product that is not FT seems irrational. However, seen from a deeper economic perspective this behaviour is rational because the consumers' utility preference function includes a supplementary type of utility in addition to the functional utility from the consumption of the good (Baggini, 2007; Richardson and Stahler, 2007). Such a supplementary utility may develop when the consumer wishes to support the producers and workers or cares about the production and the distribution process or feels nice from the knowledge that they are giving their money directly to the person who is growing their coffee, even if it does not affect product quality. For some consumers, the act of purchasing FT products may benefit them because they feel they are promoting their social reputation and self-esteem. Self-esteem is used in the sense of a 'feel good' factor - Richardson and Stahler, 2007 and Hayes, 2008 call it the 'warm glow effect'. If the supplementary utility exceeds any utility losses caused by the additional charge for the FT product compared with the conventional product, then the act of the consumer demanding such a product is fully rational. 
An alternative for consumers could be to obtain the supplementary utility separately, say by a relevant charitable action or donation to an aid organisation. An attraction to buy FT products is that the FT purchase does not cause additional transaction costs for the consumer, such as expenses of or time necessary for the collection of information about alternative charitable causes. ${ }^{3}$ The FT label allows consumers to distinguish between FT products from other products. Just as conventional products influence consumers through advertising, FT seeks to influence them through campaigning, in particular telling the consumers that their purchase will help a more equitable way of doing business. Whether FT does or does not achieve its objectives is an empirical matter, the important thing is to satisfy the subjective preferences of its consumers. It is only necessary for consumers to believe in FT or that they are doing something to help others; consumers usually do not actually assess the evidence, though they may form their opinion about FT based on what they hear and read about it. This is not unique to FT and is true with many types of market trade. For example, other alternative models of 'ethical' trading, organic and local produce as well as trading of branded products that emphasise 'social responsibility' or any particular feature in their products, are quite similar.

When it comes to producers deciding whether to join FT, they do so by comparing the demands or costs imposed by FT with the expected payoffs. FT charge producers or producer organisations for FT certification. In addition, producers are likely to incur additional expenditure in meeting the FT certification standards. It can be expected that the producer will join FT only if they expect the payoffs to be greater than the costs. It is possible that for some producers and for some regions

\footnotetext{
${ }^{3}$ The lower are the costs for moral and ethical behaviour, the higher is the willingness to act accordingly (Kirchgässner, 1992; Kirchgässner and Pommerehne, 1993).
} 
adjusting production according to FT standards may incur no great additional costs: FT activities are likely to favour such producers and regions. It may be worth noting that it is wrong to assume that producers join FT only for a price premium; they may join for considerations such as the location of production, quality of output, lack of access (or being less competitive) in other marketing institutions or a wish to diversify their marketing options. According to Dammert and Mohan (2015), access to developed country market is one of the primary reasons that producers join FT. In economic terms, producers see FT as another channel to sell their produce and will defect from FT if they feel the payoffs are not to their advantage. In principle, it is possible that a minority of producers may join FT just because they believe in it even if it does not result in obvious extra pay offs - this is similar to some producers opting for organic methods of production.

Moreover, producers are interested in selling their produce and have to explore different marketing options, particularly producers who have a marketable surplus have to "jump through hoops" to find buyers for their produce and explore as many marketing channels as possible. The supply of FT produce is purely market demand driven and given the relatively small size of the market FT producers are aware that can sell only a small share of their produce in the FT market and the rest they have to sell to the conventional or other (e.g. organic) markets. For example, coffee which accounts for the highest sale of all FT products, various field studies have found that the share of coffee an FT certified producer can sell through FT channels is often between only 10 to 30 per cent; when it comes to other FT products the share is even less (Mohan, 2010).

As would be expected, if supply exceeds demand in FT markets, this results in increased barriers to entry and increased competition among FT producers and producer organisations for securing 
FT contracts. In such a situation, similar to the free market, there is a selection process carried out by FT buyers who enjoy market power to discriminate between different suppliers. For example, in coffee, there is evidence of many FT coffee buyers demanding organic coffee and producers and producer organisations have to become organic certified if they wish to obtain FT contracts. According to Janvry et al. (2015), buyer power has resulted in fall in rents for producers and favoured commercially oriented suppliers able to meet conditions of the buyers. Buyer power is evident from the fact that it is not uncommon for producers being afraid to ask for pre-financing because they fear buyers would terminate the partnership; Pierre (2007) finds this in a study of coffee producers. Therefore from the viewpoint of producers to produce for FT is similar to producing for a speciality market or an additional channel of marketing.

Essentially, FT is an alternative form of speciality trade that is sending a market signal. FT provides an additional trade channel that, among other things, offers opportunities to particular consumers to obtain 'supplementary utility' and to particular producers the ability to access an additional marketing channel including all the benefits that may come from such an access. Just as an organic speciality market producer can benefit from the ability to sell their produce through an additional marketing channel, the same holds for an FT producer. Consumers of organic products can obtain 'supplementary utility' in the same way as consumers of FT products. However, they can benefit only to the extent of the size of the FT speciality market. The success of any speciality product brand in the market depends on price, quality and customer loyalty for the brand in relation to the competing brands. In the same way, the success of FT products hinges on their quality, price and consumers belief in FT in relation to competing brands in the market. The FT campaigning (a form of advertising) plays an important role in promoting consumers belief in FT.The extent of belief 
of a consumer in FT or for that matter any speciality brand determines the extent of their preference for that particular brand over other competing brands.

The alternative speciality market argument is supported by the food industry which produces highly differentiated products. For example, in the market, there are many different coffee products which are differentiated from one another in terms of quality, blends, packaging and also, more recently, 'environmental' and 'social responsibility' features. ${ }^{4}$ For each of these products, there exists a specific and different market price which is determined by consumer taste and preferences for that kind of product. The different sub-markets have different demand and supply curves based on the choices of consumers and producers. The specialised brands can create more inelastic demand by segmenting the market. Like the market for organic products, if the market for FT coffee supports a higher price, the signal this sends is that coffee producers should compete to capture a part of this higher price. All the costs associated with producing FT coffee are priced in the FT coffee market and consumers voluntarily pay this price by purchasing this coffee.

It is therefore wrong to consider FT as a development of a market that is different from the traditional "free market" - all that is happening is that FT opens up an alternative speciality trading channel within the free market. The market fundamentals, the demand, supply and market competitiveness conditions for FT products follow conventional trading practices.

\footnotetext{
${ }^{4}$ The alternative product qualities of organic, shade grown, single origin or FT coffee is distinguished in the market by the use of certification (logo or mark). The consumers of these products tend to associate the certification to symbolise ecology, flavour, regional identity or social solidarity.
} 
For the last six decades, the issue of primary agricultural commodities has given rise to a large body of literature according to which the primary commodities are plagued with long-term declining prices (Prebisch-Singer theory) and low share of the final product price reaching the producers particularly in the developing countries (ActionAid, 2008). As to declining prices, most analyst agree that the main problem is an oversupply of many agricultural primary commodities in the market resulting in a decline in their real prices over time. When it comes to FT, if there is an oversupply it shall be the same with or without FT. Another related problem is that mostly processing and value addition of primary agricultural commodities takes place in developed consuming markets instead of commodity-producing developing countries. Again, there is nothing in the FT system that encourages value addition in the producing developing countries.

As to producers receiving a low share of the final product price, the main blame for this is attributed to the increased market concentration (that is, monopsony power) in the commodity markets at the international processing, trading and retailing level (Igami, 2015). However, not all agree that market concentration of the coffee market has contributed to the impoverishment of producers in terms of fall in their real income or share in the value chain. Even if we accept when there is a monopsonistic/oligopolistic market structure, prices may reflect the market power of buyers (importers, traders and retailers). The question is does FT eradicate monopsony power? Does FT organising enable producers to improve market power that results in higher prices or higher share in the value chain? The proponents of FT make tall claims on addressing the vulnerability of producers: as a part of Trade Justice campaign, FT seeks greater equity in international trade by challenging market competitiveness based solely on price, challenging "the injustices of conventional trade” and trying to create more egalitarian trade between Northern consumers and 
Southern producers. However, FT is doing no such thing. It seeks to operate simultaneously against the market and within the market, while all it appears to be doing is opening up an alternative trading channel within the market. As noted above, this does not alter the market fundamentals, the market competitiveness conditions for FT products follow conventional trade practices. FT is equally buyer-driven and FT products compete in the market just like other speciality products. Upstream actors in the supply chain exert economic and quality control taking account of the consumers' preferences. Also, similar to the trend in conventional markets, the growth of FT has been driven by corporations and international institutions.

Moreover, FT can be blamed for practising absolutism and knocking the competition. At times FT rhetoric ends up as smear campaigns against high-end marketers and retailers who resist the FT model. The campaigns tend to convey that FT is equitable and everything else is ‘exploitation' or unfair. In 2000, activist groups associated with FT launched an attack on Starbucks for allegedly mistreating farmers, whereas Starbucks by promoting speciality coffees improved the lot of coffee growers in the 25 countries from which it purchases coffee (Mohan, 2010). FT has persuaded parishes, schools, universities and towns to adopt FT label as the only acceptable standard. In 2016 the number of FT Towns were 1850. This grassroots initiative - driven by supporters campaigning for trade justice - is unique to FT (FLO, 2018). It also seems to have persuaded the Dutch government that FT label is the only ethical label. The Dutch government procurement policy announced in 2008 contains certain elements that give a virtual monopoly to FT products. This policy is being copied by the municipal governments in their tendering procedure that could make a market exceeding €100 million per year a FT monopoly. The Dutch Industry Association of Coffee and Tea and some roasters like Sara Lee (which uses Utz certification) oppose the decision 
to treat FT standard 'fairer' than others. Kolk (2012) feels that this kind of monopoly could extend beyond the public sector in the Netherlands and also to some other EU countries. FT absolutism is rolling on and it would be legitimate to express concern about the market power of FT organisations. As a part of free market economy there is nothing unethical about knocking down the competition to its own advantage, but it is difficult to describe FT's policy in this regard as 'fair' on the grounds that it is doing what it campaigns against and also because it pitches itself on a higher moral plane as compared to other initiatives.

FT and its proponents claim that by directly linking importers and consumers in the North with producers and workers in the South, it aims at empowering the latter to become stakeholders in their own organisations and actively play a wider role in the global arena, to achieve greater equity in international trade. Consumers are not connected with producers in a democratic or genuinely participatory process and their influence is limited to their 'purchasing power' in terms of their willingness to buy FT products and pay an 'ethical premium'. Their knowledge of FT and the lives of producer communities is mediated by the market through advertising and FT campaigning. For producers FT is just another channel for selling their produce; Lyon (2007) reports that only 3 of 53 coffee co-op members in Guatemala were familiar with the word FT. Therefore, it cannot be said that trading between importers and producers under FT is more direct than under conventional trade. Just because someone buys FT or producer registers to supply for FT or there is a corporate mechanism for setting standards and certification does not link the two.

It is, therefore, both simplistic and populist to assert that FT corrects inequitable trade, because FT is not changing the market basics. As far as FT's goal of greater equity in international trade is 
concerned, FT is not specific about what constitutes greater equity, nor is the idea incorporated into its standards in a concrete measurable manner. Like other niche market operations, it is developing an alternative trade channel within the market system that offers particular groups of producers an opportunity to benefit from a captive market. Admittedly, FT producers benefit from the alternative trade channel just like other speciality market producers.

\section{DOES FT MISLEAD CONSUMERS IN BELIEVING THAT MOST OF THE EXTRA PREMIUM THEY PAY FOR FT PRODUCTS REACHES PRODUCERS?}

Consumers buy FT products for consumption at home or to consume in cafeterias etc. It can be expected that consumers pay a higher price for the FT product compared to conventional products. It is not easy to calculate the price premium paid by the consumers as comparable data of FT and non-FT products similar in all respects is rarely available. While it is very difficult to calculate the premium paid by the consumers, it is equally difficult to calculate what proportion of the premium reached the country of origin of the product or the producer. The premium paid by the consumers does not enter the accounting system of the FT organisations.

In relation to the premium paid by the consumers for FT products, FT is mostly faulted for unethical behaviour on two counts. First, very little of the premium paid by the consumers reaches the producer; and second, FT misleads the consumers that all or most of what they are paying is reaching the producer. The Economist (2006) comments: 'Some consumers may be disturbed to learn that, according to some estimates, as little as ten per cent of the extra price they pay for FT coffee trickles down to the producer. This is because wholesalers, processors, branders and 
retailers each take a little of the extra price for themselves, and FT has no control over those extra dips into the profit chain. Due to opacity in the pricing along the supply chain, neither the consumers nor FT has much information over those extra dips into the profit chain' (Economist 2006). Even analysts who are sympathetic to FT (e.g., Nicholls and Opal, 2005) estimate that at most 25 per cent of the additional price a shopper pays for FT bananas would go to the producers, because of mark-ups to cover for the FT certification fees that wholesalers and traders pay to the FT organisations and to offset the costs incurred in organising the additional supply chains and marketing channels for FT products.

As to the concern that wholesalers, processors/branders and retailers add their own mark-ups to FT products, FT works in the way the free enterprise system works, it merely guarantees that a fair price and a social premium is paid to the producer, and has no way of controlling margins beyond in the rest of the supply chain. Moreover, under EU and US competition laws, it is illegal for FT to intervene in price-fixing discussions between retailers and importers. FT cites a range of studies to show that the majority of retailers do not increase their profit margins on FT products for fear of losing their market share in the growing FT market. Also, retailers are not likely to misuse FT as they are increasingly concerned about 'social responsibility' image improvement. In December 2006, for example, British retailer Sainsbury's announced that it would offer only FT bananas and this was done without any increase in the price. Undoubtedly, reputation for fairness is important for big wholesalers, processors and retailers who view it as a part of their social enterprise image as well as a strategic asset that can be leveraged to gain competitive advantage and a safety buffer that can be called upon for protection against unfavourable events like consumer boycotts (Mohan, 2010; Fitjar, 2011). 
Even if wholesalers, processors and retailers do not increase their profit margins on FT products, it would be unreasonable to expect a high proportion of the premium to reach the producer. This is because FT organisations charge certification fees from wholesalers and producer or producer organisations, which cut into the FT price premium. Producer organisations that supply to FT have to pay the initial application fee and a yearly certification fee that ranges from 1199 euros for an organisation with less than 50 members to 2839 euros for an organisation with more than 1000 members (FLO-Cert, 2016). Wholesalers that supply to retailers wishing to use the FT label pay a licence fee to the FT organisation in the country of sale. For example, the UK based 'Fairtrade Foundation' charges around 1.7 percent of sales value of FT labelled products from wholesalers that supply these products to retailers (Fairtrade Foundation, 2016).

The FT certification fees are often criticised for being excessive. It is felt that FT has grown into a complex bureaucracy and an industry in itself resulting in excessive administration and promotional costs. Consequently, FT has to charge high certification fees to cover these costs. However, one can expect FT organisations to incur costs in organising the additional supply chains and marketing channels for FT products. The systems of checking and conducting inspections all through the FT supply chain are expensive. The high expenditure on promotional activities is necessary as FT's success depends upon reaching consumers and convincing them about the philosophy and merits of FT. FT can exist as long as the willingness of the consumer to pay is high enough to cover the costs of the FT process. Certification costs, therefore, cannot be wished away as FT has to meet a large part of its costs from them, the rest from grants. 
Notwithstanding, whether the costs of organising and managing the FT process are justified or not, there is no denying the fact that a major proportion of the gain from the FT price premium is eaten up in the supply chain and, to that extent, the net premium available for redistribution to producers is reduced. In addition, producers are likely to incur additional expenditure in meeting the FT certification standards. Moreover, producers incur costs for certified production for all their produce, while they may sell only a small percentage of their output to FT channels. In addition, as noted earlier, the FT system does not alter market fundamentals and if buyers of FT products enjoy the market power it will result in fall in rents for producers (Janvry et al., 2015). Furthermore, the FT price is also limited by the need to remain somewhat competitive with conventional prices, and as a result, it has not been that higher than conventional prices by historical standards (Fridell, 2014).

There is no way a large proportion of the premium that Northern consumers pay can reach the producers. Therefore, the net premium (price received - costs on account of adopting FT) actually received by producers can be far lower than is commonly perceived. It may be worth noting that it is wrong to assume that producers join FT only for the premium; as noted earlier there can be other reasons particularly a wish to diversify their marketing options. Dammert and Mohan (2015) review past studies on price differential for coffee producers. They find that a set of studies find that FT coffee producers receive a moderate price premium over conventional producers after adjusting for costs. However, a shortcoming of these studies is that most of them compare outcomes of FT producers against producers delivering to the conventional market, but these two groups are not really comparable as there is most likely a positive selection into FT. As FT is a speciality market channel it can be expected that selection into FT is correlated with characteristics 
such as producers ability to produce a better quality coffee as well as greater ability in managing and selling produce. The moderate price premium, therefore, may be a result of this positive selection. There are also studies that find that FT producers do not receive any price premium. Fort and Ruben (2009) use propensity score matching (based on observable characteristics such as farm-size, farm tenure, age, family size, among others) to pair FT coffee producers with similar non-FT producers. The main results for 360 coffee farmers in Peru suggest no evidence on price differentials.

A point of clarification may be in order. It is not being argued that producers should get a high price premium, the relevant point is whether the consumers are being misled into believing that a large part of the premium (which itself remains unquantified) paid by them is being passed on to the poor producers in the South. An important component of the FT movement is its campaignbased promotion. The campaigning, which at times can be aggressive by proponents of FT, tends to convey the impression to FT consumers that almost all the extra cost (premium) they are paying for FT products is passed on to the producer or for the welfare of their wider community. On the part of FT, it is legal and part of the free market system, but that does not however make it ethical.

\section{DOES FT SECURE PRODUCERS AGAINST THE VOLATILITY OF MARKET PRICES?}

An FT contract involves traders paying producers an agreed minimum price that cover the costs of sustainable production and living, which gives way to the market price whenever this is above the minimum price. A literal interpretation of the contract condition of minimum price has resulted 
in the propagation of the view that FT protects risk-averse primary product producers against the volatility of market prices, particularly in volatile tropical commodity markets. FT coffee seeks to counter falling producer prices, international market volatility and vulnerability of small-scale producers (Grodnik and Conroy 2007). One of FT's goals for the coffee industry is to move marginalised producers and workers to a position of economic security. FT attempts to achieve this through the use of a voluntary price floor, decreasing the downside risk to the producer. In effect, FT seeks to operate as a very simple hedging device for small farmers and take credit for 'reducing the vulnerability of producers to market and non-market crises'. Strictly speaking, the contract offered to FT producers is more like a 'put options' contract because FT suppliers also receive higher prices if the market price of the product rises.

However, these interpretations run into problems when seen in the practical context for producers. This is because producers are not concerned with price per se, price is important to them to the extent it affects their income. Although FT offers a minimum guaranteed price, it does not guarantee the quantities that traders will buy. Under the FT contract, there is no guarantee or enforceable commitment on traders to buy the output from producers. ${ }^{5}$ In other words, producers cannot plan their production based on the FT minimum price as there is no certainty on the quantity of produce that will be purchased by the FT trader. Therefore, the FT minimum price guarantee cannot match a 'put options' contract.

In defence of FT, one could argue that it does encourage buyers to purchase directly from producers or producer organisations with purchasing agreements (oral/non-binding) that extend

\footnotetext{
${ }^{5}$ Under the FT contract producers too are free to supply their produce in the FT market or any other market.
} 
preferably beyond a harvest cycle. Even if such an agreement exists, it is doubtful that producers can enforce it as in primary commodity markets the balance of power usually favours the buyers. As there is usually oversupply in commodity markets it is easy for buyers to switch between producers. Besides, if the world prices move significantly against the buyer, it is easy for them to renege on their purchase commitments as the agreements are non-binding (i.e. not legally enforceable).

Moreover, commodity markets are notorious for their complexities, which can cause prices to fluctuate over a wide range (Mohan and Love, 2004; Mohan, 2007). If this adversely affects FT buyers, even well-intentioned buyers will find it difficult to keep their commitments. In conventional markets, some commercial buyers of commodities, including transnational export firms, do guarantee prices to suppliers in order to bring stability to the supply chain, but they do so only after hedging their risk from variable prices. For example, elevator operators of wheat and corn in the US routinely hedge themselves from market instabilities through forward and futures contracts; this enables them to offer pre-announced minimum prices for assured quantities to their suppliers (Mohan, 2007).

Therefore, FT producers remain equally vulnerable to global markets in the same way as conventional producers. Moreover, they are dependent on the FT certification system over which they have limited or no control. Nevertheless, FT is definitely responsible for the creation of an alternative trading channel that serves the purpose of market diversification for some producers. FT deserves credit for this, but it cannot trumpet that it is offering FT producers security from 
volatility in market prices because it can guarantee neither the quantities that will be bought nor a stable income for a producer.

\section{HOW THE BENEFITS OF FT COMPARE WITH THOSE OF OTHER SIMILAR TRADING RELATIONSHIPS OPERATING IN THE MARKET?}

In the earlier discussion we concluded that FT is like an alternative/additional speciality or niche market trading channel that operates within the market system. It offers some producers opportunity to benefit from this trading channel, producers that join it accept its conditions and all the benefits and costs that come with it. As it is voluntary for producers to join it can be expected that overall they will benefit from joining this trading channel - the main benefits for producers are listed below.

- In a market system creation of an alternative trade channels can create more inelastic demand by segmenting the market. This is endorsed by simple economic theory as well as by field studies such as Bacon (2005) on organic and speciality coffee producers in Northern Nicaragua. This offers an opportunity to some producers to benefit from this inelastic demand: the benefits can be capturing a share in the price premium (as discussed in Section 4) and to potentially reduce the market risk exposure of producers through access to an additional marketing channel. In addition, FT benefits producers by providing them with guaranteed minimum prices that at times may be higher than conventional world market prices. This can provide economic benefit to producers when market prices fall below this price, though this 
benefit is limited to the quantities of the product that traders are willing to buy when the guaranteed FT minimum price is higher than the conventional market prices.

- It can be expected that joining FT builds the organising capacity of producers to benefit from a niche market (i.e. ability to meet conditions, paperwork etc. for certification). This can enhance the production and marketing skills of producers that extend beyond FT into wider production and marketing. When it comes to FT producers of coffee and cocoa, they are required to belong to producer co-operatives or unions. Although there are differing findings of field-studies on the advantages and disadvantages of co-operatives for FT producers, in principle, one can expect the co-operatives to allow producers to take advantage of economies of scale to bargain more effectively with large buyers of products. In addition, good cooperatives, though examples of such are very few, help by negotiating credit and providing credit to members, providing training in farming techniques, particularly organic farming and organising organic certification, improving quality control and building relations with foreign importers. ${ }^{6}$ When it comes to workers in large enterprises FT does help in improving their bargaining power by requiring the workers to be organised in democratically formed unions. FT is criticised by some for its insistence on coffee and cocoa producers joining a co-operative in order to be allowed to supply the FT market. It is felt that this discriminates against those producers that satisfy the other FT standards but who do not want to join a co-operative. Moreover, the poorest producers are the least likely to benefit from FT because they are generally not organised in co-operatives for various reasons - several studies show that partnerships are not formed with the poorest (Hopkins, 2000; Taylor, 2002; Belgian Science Policy, 2005). FT preference to use co-operatives for coffee and cocoa is because they have

\footnotetext{
${ }^{6}$ There is lot of evidence of co-operatives functioning undemocratically and not always working in the interest of producers; corrupt co-operatives may not pass on all the legitimate benefits to producers.
} 
traditionally been supplied by small-scale producers and co-operatives can provide an affordable mechanism for FT participation including a kind of central management crucial to checking that the FT standards are being met. However, Fair Trade USA (a former member of Fairtrade International under the name Transfair USA) believes that unorganized producers should also be certified. This difference was a fundamental reason for Transfair USA's split from Fairtrade International in end 2011 and its subsequent certification of some larger producers under its own label.

- In addition to the price, FT buyers provide FT producers or producer organisations a social premium (around 5 per cent of the minimum price) to finance common production facilities and wider community projects. Projects that are typically funded with the FT premium include investments made to increase farmer productivity; investments in community infrastructure such as the building of schools, health clinics, and crop storage facilities; offering training for members of the community; the provision of educational scholarships; improvements in water treatment systems; conversion to organic production techniques; and so on. For larger enterprises the social premium is intended to enhance worker welfare through investments in training, equipment, ownership shares and broader community welfare through the provision of various social services. The social premium is expected to help directly or indirectly producers and workers and their wider community - in 2015 an estimated $€ 138$ million in FT social premium was disbursed (FLO, 2017).

- As per the FT contract, FT buyers agree to develop long-term relationships (one year or more) and to provide some advance pre-financing credit to producers or producer groups (up to 60 percent) if requested. It is difficult to obtain accurate estimates of the extent of pre-financing being provided to producers' under this provision. Although, the provision exists it seems not 
many producers take benefit of it: Kohler (2007) study finds that it is not uncommon for coffee producers being afraid to ask for pre-financing because they fear buyers would terminate the partnership. However, producer organisations benefit from the FT Access Fund, which loaned 11.1 million to small producer organisations in 2014 (FLO, 2015).

FT is one of the many voluntary social labelling standards that have emerged. These labelling standards share some common overlapping goals but each has its own focus and priorities. In addition to FT, other social certification standards include Organic, Rainforest Alliance, and UTZ Certified, and there are similarly prominent labels for different products such as those of the Forest Stewardship Council, Marine Stewardship Council, Roundtable on Sustainable Palm Oil, and Global G.A.P. ${ }^{7}$ The benefits of FT are more or less similar to other social labelling trading channels in the market as evident from Table 2 which presents a comparative overview of costs and benefits for producers joining a social labelling trading channel for coffee. In the case of coffee, three other speciality trading channels - Organic, Rainforest Alliance (RA) and Utz have gained prominence. The starting point for Organic and RA is the protection of ecosystems and biodiversity; for Utz, it is market-based mainstreaming sustainability. From Table 3 it can be seen that unlike FT, other standards do not assure producers a fixed price, but generally the prices offered are significantly higher based on the niche market demand and supply conditions (Kolk 2012). This is so because of the quality improvement in production, especially in the case of RA and Utz, fetches higher prices for producers. Entry barriers for producers vary across these trading channels, in general

\footnotetext{
${ }^{7}$ For information on Organic, see the website of the International Federation of Organic Agricultural Movements at http://www.ifoam.org. For information on UTZ Certified, see https://www.utzcertified.org. For Rainforest Alliance, see http://www.rainforest-alliance.org. For Forest Stewardship Council, seehttps://us.fsc.org. For Marine Stewardship Council, see http://www.msc.org. For Global G.A.P., see http://www.globalgap.org.
} 
they are higher for organic, though lately many producers are adopting organic because of growing market demand and higher price premium.

Despite several studies on the different social labelling schemes, it has not been possible to draw definite conclusions as to which system is best for producers. Most impact studies relate to just one standard and rarely have good baselines and are based on self-reported surveys with various biases. Also, most studies do not include control groups. In comparing different coffee trading schemes there is also the issue of producers selling only a small proportion of their produce under a particular scheme. In addition to these sustainable schemes, there are other corporate programmes like CAFÉ (from Starbucks) and AAA Nespro (from Nestlé) - these programmes emphasise quality and producers supplying under these programmes are reported to earn a high price premium and also benefit from long-term relationship with the buyer. Janvry et al. (2015) study finds that corporate buyers and even conventional markets reward coffee quality in terms of a price premium over FT and other social labelling markets.

\section{[Table 2 here]}

\section{CONCLUSION}

There are strong reasons to reject the views popularised by enthusiasts of FT that it corrects the injustices and inequities of conventional trade in favour of marginalised producers and workers; that it guarantees stable income for producers securing them against the volatility of market prices; and that almost all the extra premium they pay for FT products benefits FT producers. FT needs 
to be viewed as a niche market alternative trading channel that operates within the free market and offers some benefits to its target group. It is important to recognise the costs and benefits of FT, which are more or less similar to other alternative market trading channels that operate within the market. Therefore FT should be seen as a niche market movement similar to organics and other social marketing and labelling initiatives.

A question that arises is whether trading in FT makes the business or enterprise 'social'? The analysis in this paper shows that in terms of 'social enterprise' context, FT should be treated no differently from other similar social marketing and labelling initiatives. Although the FT concept matches closely to that of 'social enterprise' and FT may have contributed to shaping of 'social enterprises' theoretical concepts, yet given the costs and benefits of FT analysed in this paper, it seems referring FT trading and businesses as obvious examples of 'social enterprises' would mean dilution of the social context expected of 'social enterprises'.

Finally, if FT restricts itself to the modest claim of being a niche market movement similar to other social marketing and labelling initiatives, rather than pitching itself as a counterweight to the vagaries of the market, it would result in greater clarity and transparency in what FT is doing and the direction it should take for its sustained growth. It will also help FT realise better opportunities such as convergence between FT and Organics, the development of internet marketing networks, and co-operation with similar social marketing and labelling initiatives, as well as improve the credibility of FT’s campaigning. 


\section{REFERENCES}

Action Aid (2008). Commodity dependence and development: Suggestions to tackle the commodities problem. Johannesburg and Geneva: Action Aid and the South Centre.

Bacon, C. (2005). Confronting the coffee crisis: Can Fairtrade, organic and speciality coffee reduce small-scale farmer vulnerability in Northern Nicaragua? World Development, 33(3), 497511.

Baggini, J. (2007, March 5). Free doesn’t mean unfair. Guardian, p. 29.

Belgian Science Policy (2005). A fair and sustainable trade, between market and solidarity: diagnosis and prospects. Final Report, Brussels: Belgian Science Policy.

Dammert, A.C. \& Mohan, S. (2015). A survey of the economics of Fair Trade. Journal of Economic Surveys, 29(5), 855-868.

Economist (2006, December 7). Voting with your trolley. Economist, London.

EU (2009). Opinion of the European Economic and Social Committee on Fairtrade food products. Official Journal of the European Union, 318, 29-34.

Fairtrade Foundation (2016). Available at: http://www.fairtrade.org.uk/en

FLO (2016) Annual Report 2014-15. Bonn: Fairtrade International.

FLO. (2017) Annual Report 2015-16. Bonn: Fairtrade International.

FLO. (2018) Annual Report 2016-17. Bonn: Fairtrade International.

FLO-CERT (2016). Fee system small producer organization: Explanatory document. Mimeo

Fitjar, R.D. (2011). Little big firms? Corporate social responsibility in small businesses that do not compete against big ones. Business Ethics: A European Review, 20, 30-44. 
Fort, R. \& Ruben, R. (2009). The impact of fair trade certification on coffee producers in Peru. Wageningen Academic.

Fridell, G. (2014). Fair trade slippages and Vietnam gaps: the ideological fantasies of fair trade coffee. Third World Quarterly, 35(7), 1179-1194.

Grant, S. and Palakshappa, N. (2018). Social enterprise push or corporate social responsibility pull? The mainstreaming of fair trade. International Journal of Nonprofit and Voluntary Sector Marketing, e1625.

Griffiths, P. (2012). Ethical objections to Fairtrade. Journal of Business Ethics, 105(3), 357-373.

Grodnik, A. and Conroy, M.E. (2007). Fairtrade coffee in the US.’ In D. Murray, L. Raynolds \& J. Wilkinson (Eds.). Fairtrade: The challenges of transforming globalisation. London: Routledge.

Hayes, M. (2008). Fighting the tide: Alternative trade organisations in the era of global free trade - a comment. World Development, 36(12), 2953-2961.

Hopkins, D. (2000). Powerful learning, powerful teaching and powerful schools. Journal of Educational Change, 1(2), 135-154.

Huybrechts, B. \& Jacques D. (2008). Are fair trade organisations necessarily social enterprises? Social Enterprise Journal, 4(3), 186-201.

Huybrechts, B. (2010). The governance of fair trade social enterprises in Belgium. Social Enterprise Journal, 6(2), 110-124.

ICO (2016). Coffee Statistics. International Coffee Organisation, London.

Igami, M. (2015). Oligopoly in international commodity markets: The case of coffee. Journal of Industrial Economics, 63(2), 225-248 
ITC (2012). The coffee exporter's guide: Export impact for good. International Trade Centre, Geneva, Switzerland.

Janvry, A. D., McIntosh, C. Sadouler, E. (2015). Fair Trade and free entry: Can a disequilibrium market serve as a development tool? Review of Economics and Statistics, 97(3), 567-573.

Kirchgassner, G. (1992). Towards a theory of low-cost decisions. European Journal of Political Economy, 8(2), 305-320.

Kirchgassner, G \& Pommerehne, W. (1993). Low-cost decisions as a challenge to public choice. Public Choice, 77, 107-115.

Kohler, P. (2007). The economics of fair trade coffee: For whose benefit. VDM Publishing House.

Kolk, A. (2012). Towards a sustainable coffee market: Paradoxes faced by a multinational company. Corporate Social Responsibility and Environmental Management, 19(2), 79-89.

Lyon, D. (2007). Surveillance study: An overview. Polity Press, USA.

Mason, C. \& Doherty, B. (2016). A Fair Trade-off? Paradoxes in the governance of fair-trade social enterprises. Journal of Business Ethics, 136:451 - 469

Mohan, S. (2007). Market based price-risk management for coffee producers. Development Policy Review, 25:3, 333-354.

Mohan, S. (2010). Fair Trade without the froth .The Institute of Economic Affairs, London.

Mohan, S. \& Love, J. (2004). Coffee futures: Role in reducing coffee producers' price risk. Journal of International Development, 16:7, 983-1002.

Nicholls, A. (2010). Fair Trade: Towards an economics of virtue. Journal of Business Ethics 92(S2), 241-255.

Nicholls, A. \& Opal, C. (2005). Fairtrade: Market-driven ethical consumption. London: Sage Publications. 
Pierre, K. (2007). The economics of Fairtrade coffee: For whose benefit? An investigation into the limits of Fairtrade as a development tool and the risk of clean-washing. Working Paper no. 06/2007. Geneva Graduate School of International Studies.

Potts, J., Lynch, M., Wilking, A., Huppe, G., Cuningham, M. \& Voora, V. (2014). State of sustainability initiatives review 2014: Standards and the green economy. International Institute for Environment and Development, London.

Richardson, M. \& Stahler, F. (2007). Fair Trade. Working Paper, Australian National University, Canberra.

Smith, W., Gonin, M., \& Besharov, M. (2013). Managing social business tensions: A review and research agenda for social enterprise. Business Ethics Quarterly, 23(3), 407 - 442.

Taylor, T. (2002). Supply chain coordination under channel rebates with sales effort effects. Management Science, 992-1007.

\section{AUTHOR BIOGRAPHIES}

Sushil Mohan is Principal Lecturer in Economics and Head of the Enterprise, Trade and Sustainable Development Research Group at Brighton Business School, University of Brighton, UK. He is an applied economist with research interests on issues relating to the interaction between international trade, ethical trading and economic development. He also has a number of years' professional experience in public administration and international business development. 
Arvind Upadhyay works in the Logistics and Supply Chain Management Department at Brighton Business School, University of Brighton, UK. His research area is operations, logistics and supply chain management, sustainable supply chain and project management.

Nikos Daskalakis is Senior Lecturer in Finance and Financial Management at the University of Brighton, UK. His current research interests lie on the scientific areas of access to finance, financial innovation, and fair trade practices.

Ridhima Mohan is an independent researcher with interest in international development issues, particularly in the production and trading of organic products. She works in the financial technology sector and specialises in the development and marketing of innovative financial products across the US and the UK. 